\title{
Constraints Faced by Banana Growers and Other Intermediaries in the Prayagraj District of Uttar Pradesh
}

\author{
Setu Ratnam ${ }^{1 *}$, Sanjay Kumar ${ }^{2}$ and Amit Kumar Masih ${ }^{3}$ \\ ${ }^{1}$ Department of Agricultural Economics, Sam Higginbottom University of Agriculture, \\ Technology and Sciences, India \\ *Corresponding author
}

\section{A B S T R A C T}

\section{Keywords}

KMO-Barlett test, Varimax rotation,

Test-fittingness,

Factor analysis,

Constraints,

Article Info

Accepted:

14 November 2020

Available Online:

10 December 2020
This study undertook in the area of kaurihar block of Prayagraj district of Uttar Pradesh where 134 farmers/ banana growers and 36 wholesale intermediaries, 16 other intermediaries and 63 retailers from wholesale and retail markets respectively were selected for constraints based study. It helped to access the major issues faced by the various shareholders of production and marketing linkages in the area. All the probable issues were divided into various factors and then they were sub-grouped further to gather maximum loading as per most effectual were segregated with load. Foremost the fittingness of data was checked by KMO test and varimax rotation matrix used to obtain factors with meaningful values that added upon by factor analysis of the existing issues. Financial issues, integration issues, government interventions infrastructural inadequateness and many other sub-groups were major perpetrators which hampered the better growth and market stability.

\section{Introduction}

The improvement of agriculture, chiefly in developing/ second world countries trails certain discrete developmental phases. The first phase of farming is of a subsistence temperament, wherein the farmers produce for their utilization, usually, most of the under-developing countries and the majority of developed countries follow this segment. The second phase is illustrated by commercial farming wherein the farmers practice farming not only for their consumption but also for the existing market as well. While the key intention of production in the first phase is to optimize the ability of survival, in the second phase the major apprehension is profit maximization either by keeping the costs even or by reducing the cost of production at a given point of total revenue. ${ }^{[3]}$ 
In India, the sense of profit-making is on the brink for the major farming population due to the marginalized farming community. Both methods revolve around one objective namely improving productivity. The central Government of India has lately commenced an abundance of measures to advance the production in the prominent horticultural sector. These actions include the extension as well transfer of technology mission for integrated and importunate development of the horticultural sector, initiation of the National Horticulture Mission which will ensure doubling the horticultural production in 2012, creation of additional cold storage as frigidarium by the National Horticulture Board, developing various agriculture economics zones supporting the export of Agri-Horti produces and allocation of an additional budgetary allotment for the HiTech Horticulture parks, plantation cultivation, precision farming, green housings and zero budget farming. ${ }^{[4]}$

Indian being the major fruit and vegetable basket of the world and having positioned as $\mathrm{II}^{\mathrm{nd}}$ in the world on production ranking but does not follow the world trends of exporting the fruits and vegetables to that extent. The major fruits being Guava, Grapes, Banana, Sapota, Citrus, Apple, Mango, Pine Apple, Papaya and Strawberry, etc. has been bestowed on India. The future of the Indian food supply chain is astonishingly vibrant due to changing lifestyles, increasing urbanization, unitary family system, increasing disposable income, and private partnership. Market penetration as well as the competently organized retail sector has improvised the chances of tremendous growth in the food sector. Government policies of establishing the special agri-zones and various food parks, incrementing expenditure on healthy food, and functional food demand have paved the glorious sector of food to flourish in forthcoming prospects. [2]
Prayagraj being the belt for guava production evidently has proclaimed increasing production in banana day by day due to proximity to Kaushambi which is being ghetto for banana production and marketing. Also the crop damages due to Neelgay have been one of the reasons to diversify the cropping pattern in the area.

The Phalprapti Schemes which were undertaken in this area due to interventions of District Horticulture Board had provided thrust to banana production along with variant subsidy to micro-propagated suckers.

\section{Materials and Methods}

The state has highest population in country and that varies from various area, the eastern and western parts of Uttar Pradesh has very high population density due to riverine land and plateau such as bundelkhand and hilly region of Himalayas has quite lesser population density. More the population more the labour supply and this becomes valuable for any developing country like India but on the other hand they are devourer of large resources and brings down per capita income to lesser extent.

The state relies on agriculture being 76.78 percent of the population directly or indirectly getting employed by this sector. Thus the state is leading producer of fruits, potato and food grain and bragging second position in oilseed production. This production is possible due to a wide stretch of alluvial plain which lies all along the length of the state where total net sown area is 27 percent is performing double cropping pattern and 29 percent have irrigations access.

The fertility leads to wide variety of crop to be grown in the area, but due to economic value only a set pattern of crop are grown and specific cropping system is followed over a 
largely distinctive area of state. Eastern districts share fairly good rainfall with small and fragmented plots as well poor draught power, wheat rice pattern is predominant and thus various other crops are not grown in this area. This minimizes the substitution capacity for other corps. Though the western region with 45 inches of rainfall and larger holding with black soil allows a variety crops to grow in both Rabi and kharif seasons.

The area covered under irrigation which accounts up to 40 percent roughly has technical advancement in agriculture. This helps in practicing modern and advanced agricultural technologies and specifically in pulses and wheat. The state confirms lower than average national productivity but that can be blamed upon defective cropping pattern and inefficient resource utility.

On the stage of literacy the district has 72.3 percent literacy when compared to state average 67.7 percent. Whereas, 48.38 percent of female are literate when compared to male which is 76.82 . The gross irrigated area has been 186.3 thousand hectares in which net irrigated area is to be distributed as 130 hectares and rain fed area is about 15.3 hectares.

\section{Block kaurihar}

Kaurihar block has very reasonable land area making it one of the largest block of the district Prayagraj, ascertaining reported area of 25455 hectare under which 38 hectare were under forest, arable land had 1290 hectare into account and fallow land had been 1698 hectare, other fallow land had been 1340 hectare, unused land were 1811 hectare and other then agriculture were about 1811 hectare, grassland captured about 32 hectare and lastly the gardens which were used for plantation cropping had been 715 hectare during 1991-92. but drastic changes can be estimated till 2015-16, the total reported area had became 44180 hectare which were under utility, the uses were as forest, arable land, current fallow, unusable land, land for other than agriculture, grassland and garden could be estimated respectively as, 132 ha, 430ha, 9181 ha, 3294 ha, 1235, 9736 ha, 60 ha and 715 ha.

\section{Selection of area}

A list of all banana producer households/respondents was prepared with the help of concerned village pradhans/head of the each selected villages in both the blocks. Thereafter a complete list of all banana producers were arranged in ascending order on the basis of their land holdings, and then the banana growers were categorized into 3 size groups on the basis of their land holdings.

I $^{\text {st }}$ Size Group - (Small banana producer households) - less than 1 ha

II $^{\text {nd }}$ Size Group - (Medium banana producer households) $-1-2$ ha

III $^{\text {rd }}$ Size Group-(Large banana producer household) - more than 2 ha

Then 20 percent sample banana producer/ growers are selected by random sampling technique, from randomly selected villages. These market functionaries were considered for data collection regarding marketing margins of banana and other marketing charges in different marketing channel. A sum total of 16 intermediaries were selected purposively for study. The wholesale market had 36 wholesaler/ commission agent intermediaries that have been investigated. The retail markets are totally owned by the retailers without any intermediates interventions, and they counted in 69 from the sum total of 114 existing retailers for research purposes. 


\section{Methodology}

Determining the suitability of data for factor analysis using the KMO and Bartlett tests

If the value of KMO (Kaiser-Meger-Olkin) be less than 0.5, the data won't be appropriate for analysis, if its value be from 0.5 to 0.7 , the correlation between the data will be appropriate for factor analysis and if it be greater than 0.7 it will be completely suitable for this aim.

\section{Determining the number of factors}

One important thing in factor analysis is to conclude the figure of extracted factors. Although a accurate basis about determining the number of extracted factors is not given, but there are some criteria for decisive number of extracted factors as: Eigen-value criterion, the previous criterion, the criterion of variance percentage, and the test cuts criterion. Considering the fact that factor analysis is of exploratory kind, so the Eigenvalue criterion is used to extract factors, and the aim is to extract factors with Eigen values greater than one.

\section{Rotating the factors}

The goal of rotation in factor analysis is rotating the factor axes around the center of coordinates. When interpreting the factors is not possible is a simple way, rotating the factor axes is used. Therefore, in order to simplify the factor structure and interpretation we use this method. There are several methods to this aim and here Varimax rotation method was used study and the factors with values greater than 1 were extracted as meaningful ones.

\section{Factor calculation}

Factor analyzes recapitulates main variables in a limited number of factors. When these new limited factors are used in next analysis (such as regression analysis or diagnosis); some values should be used to derive new variables. These values are, in fact, a combination of all of the variables that have a major role in building the new factor. Such factors coagulate under some specific theme. This combination of variables is called a factor scores (values). Since this study aimed to use a new but limited set of factors of a combination of variables instead of main variables, in succeeding analyzes (regression analysis), so the factor values are computed to achieve this goal.

\section{Results and Discussion}

For the factor analysis table 1 estimated the agricultural issues pertaining to marketing in different sizes of farming community, exploratory factor analysis approach was used to recapitulate the data. To assure the fittingness of the collected data, the coefficient of KMO (Kaiser Coefficient and Barlett test were undertaken. Here the KMO coefficient was estimated to be 0.687 which assures the fittingness of the data for the test. Barlett test ensured the suitability with 289.4 with a significance level of 0.56 i.e. five percent significance level.

As table 2 recognized that factor analysis's exploratory in its demeanor, Eigen values are used to extract the factors which are more than one. As well Varimax rotation matrix methods were used in order to extract values greater than one to give a more meaningful result. Here there are three major factors which are deliberated from the farmer's point of view which are major constraints during banana marketing at their level. Financial issues in supply chain predictable at first level with value of 1.796 and variance of 25.65 , whereas second position is grabbed by integration issues with 1.577 , later the fragmented supply chain has minimum 
variance of 18.02 percent and Eigen value of 1.109 .

As in the table 3 can be seen that the first group of concern the highest weightage is grabbed by the disparity between farmer realization about the price at his disposal and final consumer price, as in the first matrix of financial supply chain ground, which is counted 0.869 . Government policy leakage is also a major concern as there is 0.873 weightage provided to it. Mandi price fluctuation and weak price stability due to arrival from other places grabbed the factor load of 0.788 and 0.744 .

In the integration issues of farmer at his farm level there is very less concern which is linkage in the market by the farmers. The major issue of financial supply chain is soaring with large number of intermediaries which chokes their price realization have Eigen value of 0.858 and traders supremacy counted second highest in this supply chain counter with 0.803 Eigen value. large number of intermediary existence and reliance on intermediaries have factor load of 0.721 and 0.630 respectively

For the factor analysis, in table 4 the agricultural issues pertaining to marketing in different wholesaler community, exploratory factor analysis approach was used to recapitulate the data.

To assure the fittingness of the collected data, the coefficient of KMO (Kaiser Coefficient) and Barlett test were undertaken. Here the KMO coefficient was estimated to be 0.531 which assures the fittingness of the data for the test. Barlett test ensured the suitability with 388.5 with a significance level of 0.51 i.e. five percent significance level.

As in table 5 it has been recognized that factor analysis's exploratory in its demeanor,
Eigen values are used to extract the factors which are more than one. As well Varimax rotation matrix methods were used in order to extract values greater than one to give a more meaningful result. Here there are three major factors which are deliberated from the wholesaler's point of view which are major constraints during banana marketing at their level.

There are majorly three groups of issues ascertained by the rotation method, which are infrastructural limitations grabbing 1.811 Eigen value and 26.59 percent of variance. The second foremost issue ascended to be transportation issues with Eigen value of 1549 and COV be 20.84. Later once could be identified as quality issues with Eigen value of 1.198 and COV of 17.55 .

As in the table 6, the banana production at local level is taken into account, it is ascending day by day but there are lesser warehouse facilities which are soaring problem at wholesale level with a value of 0.865 in rotation matrix. The infrastructural establishments are major issue, high storage charges lay off the major chunk of produce in the market trims down the time utility of crop, and thus high storage cost brags 0.801 in rotation matrix. Mandi cesses on horticultural crops like banana shuns down the major infrastructural problems seizing their major concern with 0.729 .

Advancing to next major concern as transportation problems, toll charges, inefficient transportation due to other cop period overlaps counted with 0.642 and 0.692 . Quality concern worth the produce is one of the major concern where uneven quality distribution, perishablity and dwindled control of product safety due to manual mishandling brags $0.651,0.546$ and 0.501 . 
Constraints in marketing of banana by farm families in different size of farms group

Number of Respondent $=104$

Table.1 KMO and Bartlett test of significance

\begin{tabular}{|c|c|c|c|}
\hline The analytical set & KMO & Barlett & Significance \\
\hline Factor affecting & 0.687 & 289.4 & 0.056 \\
\hline
\end{tabular}

Table.2 Extracted factors with the Eigen value, percent of variance and cumulative percent of variance

\begin{tabular}{|c|c|c|c|}
\hline Factors & Eigen value & $\begin{array}{c}\text { Percentage of } \\
\text { variance }\end{array}$ & $\begin{array}{c}\text { Cumulative frequency } \\
\text { of variance }\end{array}$ \\
\hline $\mathbf{1}$ & 1.796 & 25.654 & 25.654 \\
\hline $\mathbf{2}$ & 1.577 & 22.554 & 48.208 \\
\hline $\mathbf{3}$ & 1.109 & 18.026 & 66.234 \\
\hline
\end{tabular}

Table.3 Variables of each of the factors and factor loading values obtained by rotation matrix

\begin{tabular}{|c|c|c|}
\hline \multirow[t]{5}{*}{$\begin{array}{l}\text { Financial issues in } \\
\text { supply chain }\end{array}$} & $\begin{array}{l}\text { High difference between final consumers price and } \\
\text { farmer realization. }\end{array}$ & 0.869 \\
\hline & Lack of transportation for medium farmers & 0.701 \\
\hline & Fluctuation in mandi prices due to seasonal demands. & 0.788 \\
\hline & Fluctuation in farmers price for different farmers & 0.744 \\
\hline & Government policy leakage in NHM. & 0.873 \\
\hline \multirow[t]{3}{*}{ Integration issues } & $\begin{array}{l}\text { Lack of forward and backward integration at various levels } \\
\text { from farmers' point. }\end{array}$ & 0.689 \\
\hline & $\begin{array}{l}\text { Poor linkage in marketing channels in meeting local } \\
\text { production and demand. }\end{array}$ & 0.591 \\
\hline & No processing units available & 0.544 \\
\hline \multirow{4}{*}{$\begin{array}{l}\text { Fragmented supply } \\
\text { chain }\end{array}$} & Large number of intermediaries & 0.858 \\
\hline & $\begin{array}{l}\text { Traders dominating supply chain and marketing channel } \\
\text { supremacy }\end{array}$ & 0.803 \\
\hline & $\begin{array}{l}\text { Farmer more reliant on intermediaries; only source of } \\
\text { demand details }\end{array}$ & 0.630 \\
\hline & Large number of local and commission agents & 0.721 \\
\hline
\end{tabular}

Constraints in marketing of banana at wholesale level in Allahabad districts

Table.4 KMO and Bartlett test of significance

\begin{tabular}{|l|l|l|l|}
\hline The analytical set & KMO & Barlett & Significance \\
\hline Factor affecting & 0.531 & 388.5 & 0.051 \\
\hline
\end{tabular}


Table.5 Extracted factors with Eigen value, percent of variance and cumulative percent of variance

\begin{tabular}{|l|c|c|c|}
\hline Factors & Eigen value & $\begin{array}{c}\text { Percentage of } \\
\text { variance }\end{array}$ & $\begin{array}{c}\text { Cumulative frequency } \\
\text { of variance }\end{array}$ \\
\hline $\mathbf{1}$ & 1.811 & 26.59 & 26.59 \\
\hline $\mathbf{2}$ & 1.549 & 20.84 & 47.43 \\
\hline $\mathbf{3}$ & 1.198 & 17.55 & 64.98 \\
\hline
\end{tabular}

Table.6 Variables of each of the factors and factor loading values obtained by rotation matrix

\begin{tabular}{|l|l|c|}
\hline $\begin{array}{l}\text { Infrastructural } \\
\text { issues }\end{array}$ & $\begin{array}{l}\text { Inadequate marketing skills like packaging, grading, } \\
\text { standardization }\end{array}$ & $\mathbf{0 . 7 2 2}$ \\
\cline { 2 - 3 } & Lack of storage and warehouses & 0.865 \\
\hline & High storage charges & 0.801 \\
\hline & $\begin{array}{l}\text { High charges in mandi for loading unloading mandi cess and } \\
\text { other surcharges. }\end{array}$ & 0.729 \\
\hline \multirow{2}{*}{$\begin{array}{l}\text { Transportation } \\
\text { issues }\end{array}$} & Costly transportation due to toll charges etc. & 0.642 \\
\hline & $\begin{array}{l}\text { Inefficient or unavailability of transportation due to } \\
\text { overlapping of other crop periods }\end{array}$ & 0.692 \\
\hline Quality issues & Uneven quality distribution from farmers lot. & 0.651 \\
\hline & Perishability & 0.546 \\
\hline & Lesser control of product safety due to manual mishandling. & 0.501 \\
\hline
\end{tabular}

Table.7 Constraints in marketing of banana at retail level in Allahabad districts

Table.8 KMO and Bartlett test of significance

\begin{tabular}{|l|l|l|l|}
\hline The analytical set & KMO & Bartlett & Significance \\
\hline Factor affecting & 0.487 & 296.4 & 0.048 \\
\hline
\end{tabular}

Table.9 Extracted factors with Eigen value, percent of variance and cumulative percent of variance

\begin{tabular}{|c|c|c|c|}
\hline Factors & $\begin{array}{c}\text { Eigen } \\
\text { value }\end{array}$ & $\begin{array}{c}\text { Percentage of } \\
\text { variance }\end{array}$ & $\begin{array}{c}\text { Cumulative frequency } \\
\text { of variance }\end{array}$ \\
\hline $\mathbf{1}$ & 1.514 & 30.23 & 30.23 \\
\hline $\mathbf{2}$ & 1.411 & 28.42 & 58.65 \\
\hline
\end{tabular}


Table.10 Variables of each of the factors and factor loading values obtained by rotation matrix

\begin{tabular}{|c|c|c|}
\hline \multirow[t]{3}{*}{ Post harvest losses } & High wastage along supply chain, transportation and storage & 0.740 \\
\hline & High decay and quality degradation till handling to consumers & 0.841 \\
\hline & Small retailers suffer poor infrastructure. & 0.784 \\
\hline \multirow{5}{*}{$\begin{array}{l}\text { Market demand and } \\
\text { information }\end{array}$} & Uneven demand due to seasonal consumptions & 0.658 \\
\hline & Price variation due to local and interstate arrivals. & 0.799 \\
\hline & $\begin{array}{l}\text { Lack of marketing information due to uneven flow of produce } \\
\text { supply. }\end{array}$ & 0.569 \\
\hline & Market competitions. & 0.780 \\
\hline & Increased demand of organic banana. & 0.501 \\
\hline
\end{tabular}

For the table 7 , the factor analysis of the agricultural issues pertaining to marketing in different retailer community, exploratory factor analysis approach was used to recapitulate the data.

To assure the fittingness of the collected data, the coefficient of KMO (Kaiser Coefficient) and Barlett test were undertaken. Here the KMO coefficient was estimated to be 0.487 which assures the fittingness of the data for the test. Barlett test ensured the suitability with 296.4 with a significance level of 0.048 i.e. five percent significance level (Table 8).

As in table 9 it is recognized that factor analysis's exploratory in its demeanor, Eigen values are used to extract the factors which are more than one. As well Varimax rotation matrix methods were used in order to extract values greater than one to give a more meaningful result. Here there are three major factors which are deliberated from the retailer's point of view which are major constraints during banana marketing at their level.

There are majorly three groups of issues ascertained by the rotation method, which are post harvest limitations grabbing 1.514 Eigen value and 30.23 percent of variance. The second foremost issue ascended to be market information with Eigen value of 1.411 and
COV be 28.42. In the table 10, the factor weight for post harvest losses escalated highest in rotation matrix scale with 0.841 load value to higher decay and quality degradation. Market demand and information scaled issue of price variation with 0.799 factor load. Wastage in supply chain scored 0.740 on load and poor infrastructure facilities to smaller retailers scaled 0.784. Market competitions and uneven demand due to seasonal consumptions scored 0.780 and 0.658 factor load in matrix. Lack of marketing information claimed 0.569 factor loads and increase demand of organic banana was found at some places in posh area of local city and it held up with 0.501 factor load.

In conclusion, the factor loads at different possession holders have been different in various subgroups of constraints. the farmers faced issues like, High difference between final consumers price and farmer realization, leakages in NHM projects thus giving a fair scenario that it has to be addressed by the governing authority and market functionaries must be reduced, other than only the commission agent being the buyer, existence of other cooperative or giant retail frames can help them to sell their produce at comparatively better price.

Small growers have lack of organization sense and thus lack bargaining power. 
Collective effort can be made to maintain the price realization into their hands. Also, distant market availability is more or less an issue; their distress even in perishable commodity is way more. Interstate arrival reduces their price taking power ${ }^{[1]}$

At wholesale level, the infrastructural constraints are more specific to the post harvest practices, transportation as well storage under technological constraints, quality issues like uneven lot, perishable produces, lesser control over product safety can be concluded.

Retailers suffer more from lose of product due to it being climacteric and suffering much rotting and degradation. Losing quality reduces price realization, thus need to have developed storage capacity an suffer lesser wastage. They also suffer price variation due to local variety and interstate superior variety and thus the produce with lesser shelf life withers away.

\section{Application of the research}

It disintegrates and sub-categories the various major factors which are influencing the grower, wholesaler, and retailer at the same time and what can be considered in the area from better producers share in consumer rupee. The farmers must not suffer production paucity and it should help the policy maker to integrate a better policy to address the various lacunae in the process of production marketing. Also helpful for the researches for further study.

\section{Abbreviations}

ha- hectare

KMO- Kaiser Meger Oklin

\section{Acknowledgement/Funding}

1) SRF, ICAR, new delhi.

2) Author thankful to Sam Higginbottom University of Agriculture, Technology and Sciences, Naini, Mahewa East, Allahabad, 211007, Uttar Pradesh

\section{References}

1. Litan Das, M.S. Nain, Rashmi Singh and R. Roy Burman, (2014), Constraints in Marketing of Fruits as Perceived by the Fruit Growers and NERAMAC in Assam, Journal of Community Mobilization and Sustainable Development Vol. 9(2), 114117, July-December, 2014

2. Rathore, J., Sharma, A., and Saxena, K. (2010). Cold Chain Infrastructure for Frozen Food: A Weak Link in Indian Retail Sector. The IUP Journal of Supply Chain Management, VII (1 \& 2), 90-103.

3. IIHR, Bangalore. 2018: https://iihr.res.in/sites/default/files/post $\% 2$ Oharvestfinalcolour_0.pdf

4. http://hdl.handle.net/10603/43009

\section{How to cite this article:}

Setu Ratnam, Sanjay Kumar and Amit Kumar Masih. 2020. Constraints Faced by Banana Growers and Other Intermediaries in the Prayagraj District of Uttar Pradesh. Int.J.Curr.Microbiol.App.Sci. 9(12): 1842-1850. doi: https://doi.org/10.20546/ijcmas.2020.912.219 